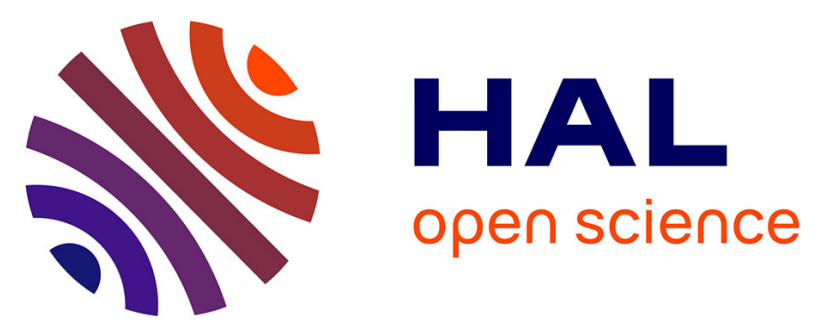

\title{
Changes in serum levels of gonadotropin, oestradiol 17 beta and vitellogenin during the first and subsequent reproductive cycles of female rainbow trout
}

\author{
C. Whitehead, N.R. Bromage, Bernard Breton
}

\section{- To cite this version:}

C. Whitehead, N.R. Bromage, Bernard Breton. Changes in serum levels of gonadotropin, oestradiol 17 beta and vitellogenin during the first and subsequent reproductive cycles of female rainbow trout. Aquaculture, 1983, 34, pp.317-326. 10.1016/0044-8486(83)90211-9 . hal-02728482

\section{HAL Id: hal-02728482 \\ https://hal.inrae.fr/hal-02728482}

Submitted on 2 Jun 2020

HAL is a multi-disciplinary open access archive for the deposit and dissemination of scientific research documents, whether they are published or not. The documents may come from teaching and research institutions in France or abroad, or from public or private research centers.
L'archive ouverte pluridisciplinaire HAL, est destinée au dépôt et à la diffusion de documents scientifiques de niveau recherche, publiés ou non, émanant des établissements d'enseignement et de recherche français ou étrangers, des laboratoires publics ou privés.

\section{다(1)(2)}

Distributed under a Creative Commons Attribution - ShareAlikel 4.0 International 
Elsevier Science Publishers B.V., Amsterdam - Printed in The Netherlands

\title{
CHANGES IN SERUM LEVELS OF GONADOTROPIN, OESTRADIOL $17 \beta$ AND VITELLOGENIN DURING THE FIRST AND SUBSEQUENT REPRODUCTIVE CYCLES OF FEMALE RAINBOW TROUT
}

\author{
C. WHITEHEAD, N.R. BROMAGE and B. BRETON* \\ Fish Culture Unit, Department of Biological Sciences, University of Aston in \\ Birmingham, Gosta Green, Birmingham B4 $7 E T$ (Great Britain) \\ *Laboratoire de Physiologie des Poissons, INRA, Université de Rennes, Beaulieu (France)
}

(Accepted 12 November 1982)

\begin{abstract}
Whitehead, C., Bromage, N.R. and Breton, B., 1983. Changes in serum levels of gonadotropin, oestradiol $17 \beta$ and vitellogenin during the first and subsequent reproductive cycles of female rainbow trout. Aquaculture, 34:317-326.
\end{abstract}

The present study investigates the relationship between changes in serum levels of gonadotropin, oestradiol $17 \beta$ and vitellogenin (by measurement of phosphoprotein phosphorus and calcium) during the annual reproductive cycle of the female rainbow trout. Two series of experiments were conducted: the first using 2-year-old previously immature fish, and the second using 3-year-old trout which had spawned during the previous reproductive cycle. The fish were maintained throughout the experiments in light-proof aquaria under simulated normal seasonal light cycles at a constant temperature of $9^{\circ} \mathrm{C}$ and feeding rate of $0.5 \%$ body weight/per day.

The fish in both series of experiments spawned by hand-stripping in mid-January at exactly the same time as other fish maintained in outside tanks under ambient conditions. Thus, photoperiod is confirmed as the major environmental determinant of reproduction in rainbow trout. A similar sequence of neuroendocrine changes was observed in both the first- and second-time spawning fish, thus indicating that similar pituitaryovarian control mechanisms are in operation in all maturing fish irrespective of age.

The initial endocrine event was an increase in the serum level of gonadotropin during the first stages of oocyte development. In the second series of experiments, which were begun in February, it appeared that minor alterations in both gonadotropin and oestradiol $17 \beta$ levels were occurring as early as March in the annual cycle. Following these changes in gonadotropin, oestradiol $17 \beta$ levels were increased to reach a maximum in the summer during the period of active exogenous vitellogenesis. After the subsequent induction of vitellogenin secretion, as evidenced by raised calcium and phosphoprotein phosphorus levels, oestradiol $17 \beta$ values fell and this decrease appeared to elicit a much greater increase in gonadotropin levels at the time of final oocyte maturation, ovulation and spawning. Vitellogenin levels did not fall until spawning had occurred. The relationship of these changes to the overall control of trout reproduction is discussed.

\section{INTRODUCTION}

Although there is considerable histological evidence for a relationship between pituitary gonadotropic cell activity and ovarian cycles in fish 
(Robertson and Wexler, 1962a, b; Sage and Bromage, 1970; Cook and Van Overbeeke, 1972), it is only with the advent of more specific and sensitive assays for gonadotropins and oestrogens that studies of the dynamic changes in blood levels of these hormones and hence their relative roles in reproduction have become possible.

Using such techniques, Breton et al. (1972) demonstrated significantly higher levels of plasma gonadotropin in goldfish on the day of ovulation, and in a later study produced similar findings for the rainbow trout and tench (Breton et al., 1975). In seasonal studies of both Atlantic and Pacific salmon and brook and brown trout, Crim et al., $(1973,1975)$ showed that plasma levels of gonadotropin were raised during maturation. Billard et al. (1978) have also demonstrated plasma and pituitary gonadotropin changes in the brown trout during ovarian development. In the same way, authors have reported seasonal changes in the levels of ovarian steroids (Schreck and Hopwood, 1974; Wingfield and Grimm, 1977; Yaron et al., 1977; Billard et al., 1978; Whitehead et al., 1978a), and higher levels of oestradiol $17 \beta$ have been correlated with ovarian development (Lambert et al., 1978).

Although these data clearly establish the separate involvement of both gonadotropin and oestradiol $17 \beta$ in teleost reproduction, only integrated studies of the interrelationships of these hormones during gonadal development enable a more complete understanding of the complex mechanisms of control. Both Fostier et al. (1978) and Whitehead et al. (1978a, b) in studies of the interplay of gonadotropin and oestradiol $17 \beta$ have shown that there is a marked increase in circulating gonadotropin levels during the period of final oocyte maturation and ovulation which is always preceded by a fall in the levels of oestradiol $17 \beta$; similar data are available for the brown trout (Billard et al., 1978; Crim and Idler, 1978). The reciprocal changes in oestradiol $17 \beta$ gonadotropin as ovulation approaches suggest a similar negative feedback relationship to that found in higher vertebrates.

These studies have in the main been concerned with the latter stages of ovarian development and consequently in the present work an investigation is made of the serial changes in serum levels of gonadotropin, oestradiol $17 \beta$ and phosphoprotein phosphorus and total calcium (as measures of vitellogenin) during the complete reproductive cycle. Both first- and secondspawning fish were studied, as Henderson (1963) has suggested that the hypothalmic-hypophyseal-gonadal mechanisms may respond differently in fish of different ages.

\section{MATERIALS AND METHODS}

Female rainbow trout, Salmo gairdneri, of Danish origin with a natural spawning time of January-February were used in this study. Two series of experiments were conducted using different groups of fish drawn from the same original stock. In the first, previously immature 2-year-old fish weigh- 
ing approximately $1.3 \mathrm{~kg}$ were used, but in the second, 3-year-old fish which weighed approximately $2.5 \mathrm{~kg}$ and had spawned once before during the preceding season were utilized. The two series of experiments were commenced in April and February, respectively, and both were completed in February of the following year. Both groups of fish were maintained in 800-1 light-proof aquaria under simulated normal seasonal light cycles provided by $40-\mathrm{W}$ fluorescent tubes (200 lux at the water surface) controlled by time clocks adjusted once per week.

The water temperature was constant at $9^{\circ} \mathrm{C}$ with a dissolved oxygen of $100 \%$ saturation in the effluent and $\mathrm{pH}$ of 6.6 . The fish were fed at a level of $0.5 \%$ body weight/day with BP Nutrition Mainstream diet. All fish were blood sampled at the start of the experiment in February and each month thereafter. Methods for sampling and subsequent assay of gonadotropin, oestradiol and calcium are described by Bromage et al. (1982a). Fish were also examined each month for signs of sexual maturation. Spawning was said to have occurred when ripe eggs were expelled after gentle hand pressure on the abdomen, i.e., stripping. Differences between means were tested statistically by either a Student's $t$-test or an $F$-test if the variances were dissimiliar.

\section{RESULTS}

The fish in both series of experiments spawned by hand-stripping in mid-January, at exactly the same time as broodstock maintained outside in open ponds under ambient conditions. During their reproductive cycles, changes were observed in the serum levels of gonadotropin, oestradiol $17 \beta$, phosphoprotein phosphorus and total calcium.

The changes in first-spawning fish are shown in Table I and graphically in Fig. 1. In April, at the beginning of the experiment, low levels of gonadotropin $(9.9 \pm 1.8 \mathrm{ng} / \mathrm{ml})$, oestradiol $17 \beta(122 \pm 11 \mathrm{pg} / \mathrm{ml})$, phosphoprotein phosphorus $(15.3 \pm 5.5 \mu \mathrm{g} / \mathrm{ml})$, and total calcium $(10.5 \pm 0.8 \mathrm{mg} \%)$ were observed.

Serum levels of gonadotropin rose to $13.2 \pm 0.8 \mathrm{ng} / \mathrm{ml}$ in July and gradually fell to $5.5 \pm 0.6 \mathrm{ng} / \mathrm{ml}$ by November. Levels in July were significantly different from those in November $(P<0.01)$. Prior to spawning in midJanuary, levels rose rapidly to a peak of $37.1 \pm 14.0 \mathrm{ng} / \mathrm{ml}$. Levels in February were also significantly different from those in November $(P<0.01)$.

During June and July, serum oestradiol levels increased from basal to $4808 \pm 1105 \mathrm{pg} / \mathrm{ml}$ in October, and then returned to resting levels before the onset of spawning in mid-January. Levels in October were significantly different from those in April $(P<0.001)$.

To enable examination of the interrelationships of these parameters the data are represented schematically in Fig. 1. As ovarian development progressed during the months of July to February, there was a significant correlation between the serum levels of gonadotropin and oestradiol $17 \beta$ 


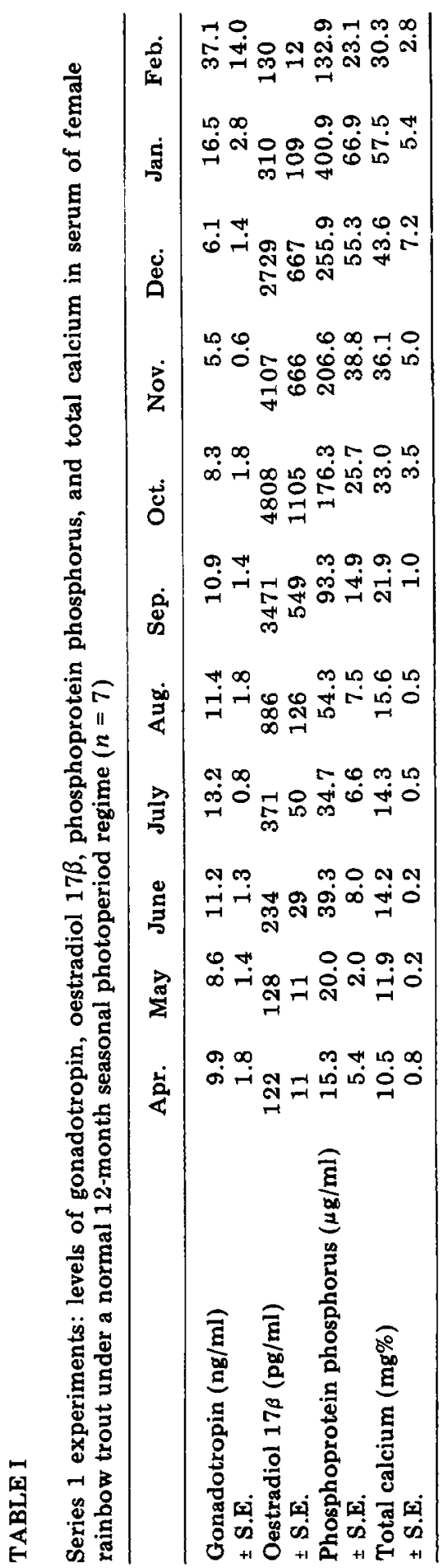




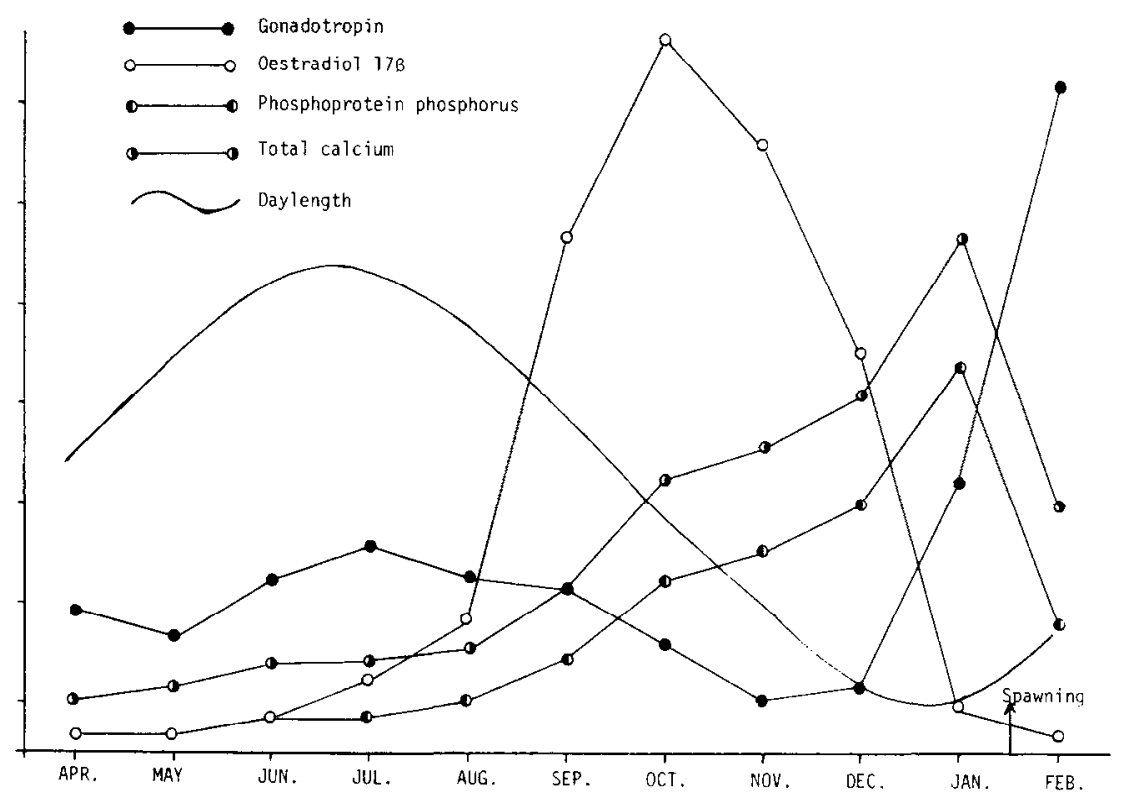

Fig. 1. Series 1 Experiments. Schematic representation of changes in levels of gonadotropin, oestradiol $17 \beta$, phosphoprotein phosphorus and total calcium in serum of female rainbow trout under a normal 17-month seasonal photoperiod regime. The fish in this series were immature at the start of the experiment.

$(P<0.001, r=0.3569, n=103)$. No correlation was found between these two hormones during the earlier stages of development (April-July) although both showed parallel increases during this period.

By September, the serum levels of phosphoprotein phosphorus and total calcium had begun to increase, reaching peaks of $400.9 \pm 66.9 \mu \mathrm{g} / \mathrm{ml}$ and $57.5 \pm 5.4 \mathrm{mg} \%$, respectively, in January. Both serum levels of phosphoprotein phosphorus and total calcium in January were significantly different from their respective levels in April $(P<0.001)$.

During the months of July to October, there was a significant correlation between the serum levels of oestradiol and total calcium/phosphoprotein phosphorus $(P<0.001, r=0.6448, n=26)$. No such correlation was found earlier (April-July) or later (November-February) in the year. Throughout the reproductive cycle a significant correlation was also observed between the levels of total calcium and phosphoprotein phosphorus $(P<0.001, r=0.8411, n=75)$.

A similar interrelationship of changes in the levels of gonadotropin, oestradiol $17 \beta$, phosphoprotein phosphorus and total calcium was observed in fish maturing for the second time although the absolute levels reached were somewhat different from those of first-spawning fish (Table II). In addition there appeared to be a slight elevation of both oestradiol and gonadotropin levels in March which was not observed in the immature fish because this experiment was not begun until April. 


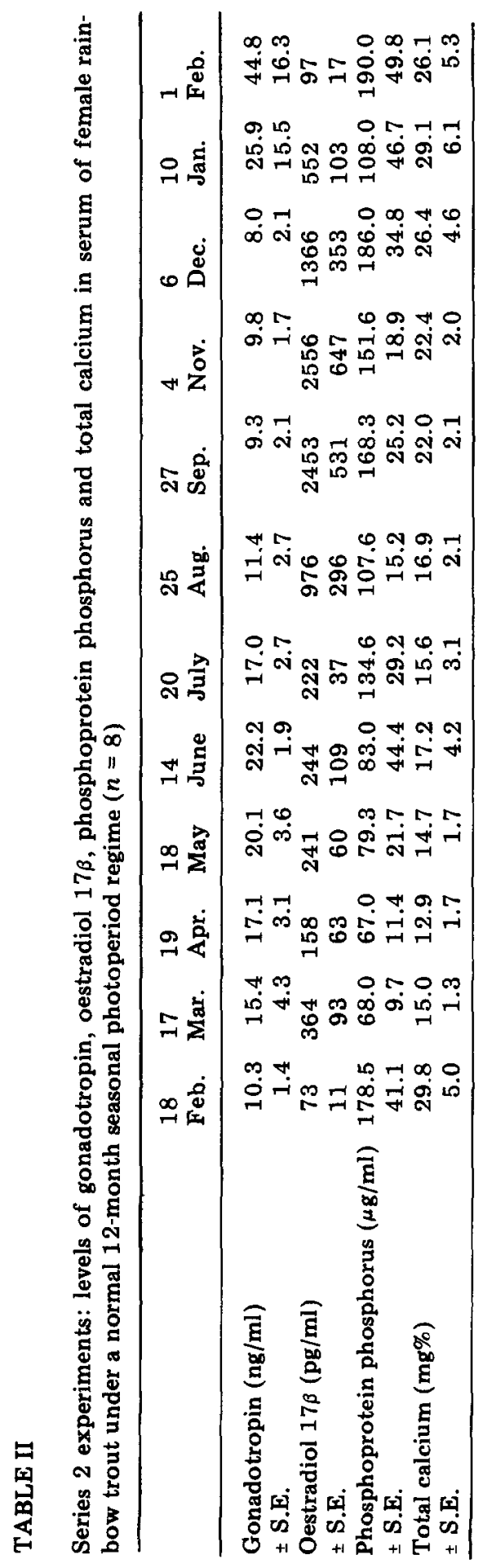




\section{DISCUSSION}

The present study clearly demonstrates similar sequences of endocrine events in female rainbow trout spawning for the first and subsequent occasion. Similar profiles have also been recorded in previously immature and also second-spawning fish exposed to modified seasonal and constant light cycles (Whitehead et al., 1978a, b; Bromage et al., 1982a, b).

It should be emphasized that under all the experimental regimes cited above and the seasonal cycles reported here that the initial event was an increase in the serum levels of gonadotropin early in the year during the period of early oocyte development, after which they returned to low levels. Prior to spawning, levels rose rapidly to a much higher value presumably during the period of final oocyte maturation and ovulation.

Although there is a wide agreement relating to the presence of high gonadotropin values in association with the later stages of ovarian development in salmonids (Crim et al., 1973, 1975; Billard et al., 1978; Bromage et al., 1982a, b; Scott and Sumpter, 1983) there is less agreement regarding levels during the remainder of the cycle. Thus, undetectable or low levels were found during gonadal recrudescence and vitellogenesis but far higher levels at ovulation in the brown and brook trout and two species of salmon (Crim et al., 1973, 1975). In a similar study Billard et al. (1978), working on the brown trout, have reported raised gonadotropin levels during the early and later portions of the spawning cycle with lower levels in the middle of the year during the first part of vitellogenesis. Fostier et al. (1978), Whitehead et al. (1978b) and Bromage et al. (1982a) have also observed higher levels of gonadotropin in rainbow trout during early ovarian development, final oocyte maturation and ovulation, but with reductions in mid-cycle. In contrast, Scott and Sumpter (1983), also working with rainbow trout, showed that high levels of gonadotropin were only present at the time of ovulation.

Although this controversy may be partly explained by differences in assay procedure, sensitivity or specificity or possibly in sampling frequency of the different studies, such disagreements will not be fully resolved until it is clear how many gonadotropins are present in fish. Several workers propose the existence of only one gonadotropin (e.g., Burzawa-Gerard et al., 1975; Breton et al., 1976; Sumpter et al., 1978) whereas others suggest that there are two (Idler et al., 1975; $\mathrm{Ng}$ and Idler, 1979). The present data provided by the results of a homologous radioimmunoassay offers some support to the presence of a single gonadotropin with different roles at different stages of ovarian development.

In the present work, after the initial increases in gonadotropin in both groups, levels fell, during which time serum oestradiol values increased. Levels of oestradiol continued to rise until October, then returned to basal values just prior to spawning in January, at which time a second and much higher peak in gonadotropin was observed. The highly significant negative 
correlations between the levels of these two hormones from July to February indicate that during the latter half of the cycle oestradiol exerts a similar negative feedback on gonadotropin secretion to that seen in higher vertebrates. This followed a period during the first part of vitellogenesis when the gonadotropin increase was followed by an increase in oestradiol. A similar cycle in levels of oestradiol $17 \beta$ has also been demonstrated in the rainbow trout by Lambert et al. (1978), and Fostier et al. (1978) have reported that oestradiol $17 \beta$ fell to a low level before oocyte maturation at a time when plasma gonadotropin was high. A similar pattern of changes in plasma oestradiol $17 \beta$ and gonadotropin has also been observed in the brown trout by Billard et al. (1978) and Crim and Idler (1978) although the latter study was not continued to the completion of the spawning cycle. Thus, the rainbow trout, like other teleost fish, has raised oestradiol $17 \beta$ levels, probably as a result of an earlier increase in gonadotropin, at a time when the developing oocytes are actively incorporating yolk.

Following the observed increase in serum oestradiol, serum levels of phosphoprotein phosphorus and total calcium were raised from an initial basal level to a peak just prior to spawning. Throughout the period of investigation there was a highly significant correlation between the serum levels of phosphoprotein phosphorus and total calcium, confirming their co-operative importance in the vitellogenin complex. During the period from July to October, a highly significant correlation was also observed between the serum levels of oestradiol $17 \beta$ and total calcium/phosphoprotein phosphorus, thus indicating that oestradiol $17 \beta$ is involved in the induction of vitellogenesis. After October, however, as oestradiol levels fell to basal, levels of serum phosphoprotein phosphorus and total calcium continued to increase, reaching a maximum just prior to spawning. Whether this reflects a continuation of vitellogenin production after return of oestradiol to basal levels, as has been reported elsewhere (Elliott et al., 1979), or whether it indicates that circulating vitellogenin is not fully taken up during this period, is not clear.

The results from both series of experiments were essentially the same, indicating that similar hypothalmic-hypophyseal-ovarian mechanisms operate in maturing fish, irrespective of whether they are spawning for the first or second occasion. However, in addition in the previously spawned fish there were modest increases in both gonadotropin and oestradiol levels in March well before the appearance of vitellogenin in the serum, and this, together with unpublished data of Breton, suggest that these hormones may already be exerting a significant influence at this early stage of ovarian development.

In summary, therefore, the results demonstrate that the changing levels of gonadotropin and oestradiol during maturation are functionally interrelated, and suggest that both positive and negative feedback mechanisms of control are involved. An increase in serum levels of oestradiol occurs early in oocyte development, probably as a result of an early increase in 
gonadotropin; as oestradiol levels increase, values of gonadotropin fall from a previously elevated level. The resulting increase in oestradiol stimulates vitellogenesis as evidenced by increases in serum phosphoprotein phosphorus and total calcium. Towards the final stages of maturation, falling oestradiol levels could provide the stimulus for the rapid increase in serum levels of gonadotropin and the consequent oocyte maturation and ovulation, this final interplay between these two hormones marking the end of the complex sequence of events required to produce a fertilizable oocyte.

\section{ACKNOWLEDGEMENTS}

This work was supported by a N.E.R.C. grant to N.R. Bromage.

\section{REFERENCES}

Billard, R., Breton, B., Fostier, A., Jalabert, B. and Wiel, C., 1978. Endocrine control of the teleost reproductive cycle and its relation to external factors: salmonid and cyprinid models. In: P.J. Gaillard and H.H. Boer (Editors), Comparative Endocrinology. Elsevier, North Holland Biomedical Press, Amsterdam, pp. 37-48.

Breton, B., Billard, R., Jalabert, B. and Kann, G., 1972. Dosage radioimmunologique des gonadotropines plasmatiques chez Carassius auratus, au cours du nycthemere et pendant l'ovulation. Gen. Comp. Endocrinol., 18: 463-468.

Breton, B., Jalabert, B., Fostier, A. and Billard, R., 1975. Etude sur le cycle reproducteur de la truite arc-en-ciel et de la tanche. Effect de variations experimentales de la temperature. J. Physiol (Paris), 30: 561-564.

Breton, B., Jalabert, B. and Reinaud, P., 1976. Purification of gonadotropin from rainbow trout (Salmo gairdneri R.) pituitary glands. Ann. Biol. Anim., Biochim., Biophys., 16: $25-36$.

Bromage, N., Whitehead, C. and Breton, B., 1982a. Relationships between serum levels of gonadotropin, oestradiol $17 \beta$ and vitellogenin in the control of ovarian development in the rainbow trout: the effects of alterations in environmental photoperiod. Gen. Comp. Endocrinol., 47: 366-376.

Bromage, N., Whitehead, C., Elliott, J., Breton, B. and Matty, A., 1982b. Investigations into the importance of daylength on the photoperiodic control of reproduction in the female rainbow trout. In: C.J. Richter and H.Th. Goos (Editors), Reproductive Physiology of Fish. Pudoc Press, Wageningen, pp. 233-236.

Burzawa-Gerard, E., Goncharov, B.F. and Fontaine, Y.A., 1975. L'hormone gonadotrope hypophysaire d'un poisson chondrosteen, l'esturgeon (Acipenser stellatus Pall). 1. Purification. Gen. Comp. Endocrinol., 27: 289-295.

Cook, H. and Van Overbeeke, A.P., 1972. Ultrastructure of the pituitary gland (pars distalis) in sockeye salmon (Oncorhynchus nerka) during gonad maturation. Z. Zellforsch. Mikrosk. Anat., 130: 338-350.

Crim, L.W. and Idler, D.R., 1978. Plasma gonadotropin, oestradiol and gonad phosvitin levels in relation to the seasonal reproductive cycles of female brown trout. Ann. Biol. Anim., Biochim., Biophys., 18: 1001-1005.

Crim, L.W., Meyer, R.K. and Donaldson, E.M., 1973. Radioimmunoassay estimates of plasma gonadotropin levels in spawning pink salmon. Gen. Comp. Endocrinol., $21: 69-76$.

Crim, L.W., Watts, E.G. and Evans, D.M., 1975. The plasma gonadotropin profile during sexual maturation in a variety of salmonid fishes. Gen. Comp. Endocrinol., 27: 62-70. 
Elliott, J.A.K., Bromage, N.R. and Whitehead, C., 1979. Effects of oestradiol $17 \beta$ on serum calcium and vitellogenin levels in rainbow trout. J. Endocrinol., 83: 54P-55P.

Fostier, A., Weil, C., Terqui, M., Breton, B. and Jalabert, B., 1978. Plasma oestradiol $17 \beta$ and gonadotropin during ovulation in rainbow trout (Salmo gairdneri). Ann. Biol. Anim., Biochim., Biophys., 18: 929-936.

Henderson, N.E., 1963. Influence of light and temperature on the reproductive cycle of the eastern brook trout (Salvelinus fontinalis Mitchell). J. Fish. Res. Board Can., 2: 859-897.

Idler, D.R. and $\mathrm{Ng}, \mathrm{T}$. Bun, 1979. Studies on two types of gonadotropins from both salmon and carp pituitaries. Gen. Comp. Endocrinol., 38: 421-440.

Idler, D.R., Bazar, L.S. and Hwang, S.J., 1975. Evidence for more than one gonadotropin in Chum salmon pituitary glands. Endocr. Res. Commun., 2: 237-249.

Lambert, J.G.D., Bosman, G.I.C.G.M., Van den Hurk, R. and Van Oordt, P.G.W.J., 1978. Annual cycles of plasma oestradiol $17 \beta$ in the female rainbow trout Salmo gairdneri. Ann. Biol. Anim., Biochim. Biophys., 18: 923-927.

$\mathrm{Ng}$, T. Bun and Idler, D.R., 1979. Studies on two types of gonadotropins from both American plaice and winter flounder pituitaries. Gen. Comp. Endocrinol., 38: 410420.

Robertson, O.H. and Wexler, B.C., 1962a. Histological changes in the pituitary gland of the rainbow trout (Salmo gairdneri) accompanying sexual maturation and spawning. J. Morphol., 110: 157-170.

Robertson, O.H. and Wexler, B.C., 1962b. Histological changes in the pituitary gland of the pacific salmon (genus Oncorhynchus). J. Morphol., 110: 171-187.

Sage, M. and Bromage, N.R., 1970. The activity of the pituitary cells of the teleost Poecilia during the gestation cycle and the control of the gonadotropic cells. Gen. Comp. Endocrinol., 14: 127-136.

Schreck, C.B. and Hopwood, M.L., 1974. Seasonal androgen and oestrogen patterns in the goldfish, Carassius auratus. Trans. Am. Fish. Soc., 103: 375-378.

Scott, A. and Sumpter, J., 1983. A comparison of the female reproductive cycles of Autumn-spawning and Winter-spawning strains of rainbow trout (Salmo gairdneri Richardson). Gen. Comp. Endocrinol., in press.

Sumpter, J.P., Follett, B.K. and Dodd, J.M., 1978. Studies on the purification of gonadotropin from dogfish (Scyliorhinus canicula L.) pituitary glands. Ann. Biol. Anim., Biochim. Biophys., 18: 787-791.

Whitehead, C., Bromage, N.R. and Forster, J.R.M., 1978a. Seasonal changes in reproductive function of the rainbow trout (Salmo gairdneri). J. Fish Biol., 12: 601-608.

Whitehead, C., Bromage, N.R., Breton, B. and Billard, R., 1978b. Effects of altered photoperiod on serum gonadotropin levels and spawning in female trout. J. Endocrinol., 79: 29P-30P.

Wingfield, J.C. and Grimm, A.S., 1977. Seasonal changes in plasma cortisol, testosterone and oestradiol $17 \beta$ in the plaice, Pleuronectes platessa L. Gen. Comp. Endocrinol., $31: 1-11$.

Yaron, Z., Terkatin Shimony, A., Shaham, Y., Salzer, M., 1977. Occurrence and biological activity of oestradiol $17 \beta$ in the intact and ovariectomised Tilapia aurea (Cichlidae, Teleostei). Gen. Comp. Endocrinol., 33: 45-52. 